\title{
Ground Water Quality Assessment for Land Productivity Mapping using GIS Techniques in Shrirampur Tehsil (Maharashtra)
}

\author{
Dr. S. P. Cholke \\ Department of Geography, R. B. N. B. College Shrirampur
}

\begin{abstract}
In present study the correlation between ground water quality and land productivity was calculated; negative impact of GWQ Index on Land productivity Index is cleared noticed. It is observed that in the villages Kadit BK, Khokar, Karegaon, Matulthan, Khandala, Khanapur and Takalibhan has very low GWQ Index (0 to 2.9) therefore ground water quality is excellent which increased land productivity Index between 220 to 255 but in the village Bhokar, Matapur and Eklahare GWQ Index has been observed (between 13-27) therefore water is more polluted which declined land productivity Index 140, 150 and 150 respectively due to extensive use of fertilizers and over irrigation in agriculture and discharge of molasses into the open ground therefore it is the need of the hour that the system of agriculture should be revitalized, for increase land productivity.
\end{abstract}

Keywords: GWQ Index, GIS, Agriculture, Land Productivity Index, Correlation

\section{Introduction}

Ground water is important source of drinking and agricultural practices in the drought prone zone in the Maharashtra. In recent years, an increasing threat to availability as well as the quality of ground water. The quality of ground water depends on physical, chemical and biological factors therefore difficult to analysis hence, a GIS-based ground water quality index (WGQI) method is one of the most effective tools to determining the quality for drinking and agricultural purposes (Burrough, 1986). The drought prone zone in the Maharashtra is not in position to achieve the agricultural growth; even the irrigated areas are facing the problem of retarding the land productivity due ground water pollution. The some of the villages in the Shrirampur tahsil are facing problem of low productivity which declining due to increased in ground water pollution. The important rivers/streams traversing the tahsil are Pravara and Godavari. Last few decades, the use of chemicals and fertilizers has increased to enhance the yield of sugarcane crop. The pollutants of these pesticides leach through soil to reach the water table. Therefore it is the need of the hour that the system of agriculture should be revitalized, to increase land productivity.

\section{Study Area}

Shrirampur Tahsil is located in the North part of Ahmednagar district of Maharashtra state and is extended between $19^{\circ} 45$ to $20^{\circ} 30 \mathrm{~N}$ latitudes and $74^{\circ} 00$ to $74^{\circ} 30 \mathrm{E}$ longitudes. The total geographical area of the tahsil is $579.87 \mathrm{sq} . \mathrm{km}$ which covers 54 villages. The net cultivated area is 480 sq. $\mathrm{km}$. About $70 \%$ of the area is irrigated by canal and dug wells, putting high pressure on groundwater resources of the Tahsil. The total population of tahsil is 2 , 56,441 (Census, 2001) and almost $80 \%$ of the workforce is engage in the agriculture, horticulture, animal husbandry and Sugar Industries. The groundwater resources are being polluted because of surface water pollution through over irrigation, high consumption of chemical fertilizers and agro based industry. The Tahsil has a sub-tropical monsoon climate. March, April, and May are the hottest months while December and January are the coldest. The maximum temperature recorded during summers is about $44^{\circ} \mathrm{C}$ and it is as low as $8^{\circ} \mathrm{C}$ in winters. The Tahsil receives an approximate average rainfall of $550 \mathrm{~mm}$ and more than $75 \%$ of which occurs during the monsoon period (JulySeptember).

\section{Methodology}

In the present study, ground water samples were collected from 50 wells, tube wells and hand pumps from different villages in Shrirampur Tahsil in January 2010. Simultaneously, GPS readings were taken for latitude, longitude, and height above mean sea level (MSL). Each of the groundwater samples was analyzed for 13 parameters.

\subsection{Ground Water Quality Index}

The total CGQ Index values where obtained by summing the water quality weights of individual water quality parameters to enable evaluation of extent of water pollution and its spatial variation for the area corresponding to different villages. GWQI map generated in the Arc GIS 9.3 for the area using spatial interpolation techniques.

\subsection{Land Productivity Measurement}

The land productivity was calculated using Storie index of productivity

$$
\text { Land productivity }(\mathrm{LP})=(\mathrm{A} / 100) \times(\mathrm{B} / \mathrm{l00}) \times(\mathrm{C} / 100) \times
$$$$
(X / 100) \times 100
$$

Finally, lands were graded into 10 groups on the basis of LP ratings from 65 to 225; higher land productivity value implies that the land in the village is more productive and Land productivity map was generated using ArcGIS 9.3 software using spatial interpolation techniques. 


\section{International Journal of Science and Research (IJSR) \\ ISSN (Online): 2319-7064 \\ Index Copernicus Value (2013): 6.14 | Impact Factor (2015): 6.391}

\subsection{Impact Assessment}

Correlation between Values obtained by both map was calculated by Pearson's Coefficient of Correlation technique. The functional form of linear relationship has been measured by using regression equation $\mathrm{Y}$ on $\mathrm{X}$ i.e.

$$
\mathbf{y}=\mathbf{a}+\mathbf{b x}
$$

The rate of change in dependent variable has been estimated with the help of ' $b$ ' coefficient, which is the line of best fit on the basis of this results, conclusion are drawn.
The groundwater sample of 50 villages were collected and each of the groundwater samples was analyzed for 13 parameters such as $\mathrm{pH}$, Electrical Conductivity (EC), TDS, Total Hardness (TH), Sodium (Na+), Potassium (K), Calcium (Ca), Magnesium ( $\mathrm{Mg}$ ), Total Alkalinity (TA) as $\mathrm{HCO}$, Chloride $(\mathrm{Cl})$, phosphate $\left(\mathrm{PO}_{4}\right)$, Sulphate $\left(\mathrm{SO}_{4}\right)$ and Iron(F) using standard procedures recommended by APHA and GWQI scores calculated and presented in Table 1. GWQ Index map is generated in the Arc GIS 9.3 with regarding the spatial variation of different water quality parameters associated with different water quality factors.

\section{Results and Discussion}

Water quality classification based on GWQ Index Score

\begin{tabular}{|c|c|c|}
\hline $\begin{array}{l}\text { GWQ Index } \\
\text { Score }\end{array}$ & Water quality & Name of Villages \\
\hline 0 to 2.9 & Excellent & Kadit BK, Khokar, Karegaon, Matul Than, Khandala, Khanapur Takalibhan \\
\hline 2.9 to 4.3 & Good water & $\begin{array}{l}\text { Nimgaon Khairi, Mankal Wadgaon, Bhamathan, Undirgaon, Mal Wadgaon, Barhmangaon, } \\
\text { Dighi, Shrirampur, Belapur, Mandve, Gondhavani, Kadit }\end{array}$ \\
\hline 4.3 to 7.2 & Poor water & $\begin{array}{l}\text { Gujarwadi, Bheradapur, Pedegaon, Fatyabad, Ainatpur, Nipani Wadgaon, Kanhegaon, Wangi } \\
\text { Kh. Haregaon, Gumandeo, Malewadi, }\end{array}$ \\
\hline 7.2 to 13 & Very poor water & $\begin{array}{l}\text { Naur, Rampur, Kamalpur, Wadala Mahadeo, Khridi, Malunje Bk, Ladgaon, Uambargaon, } \\
\text { Wadatgaon, Kurranpur, Gondegaon, Galnimb, Ukkhalgaon, Nursari }\end{array}$ \\
\hline 13 to 27 & $\begin{array}{l}\text { Unsuitable } \\
\text { for Drinking }\end{array}$ & hokar, Matapur, Eklahare, \\
\hline
\end{tabular}

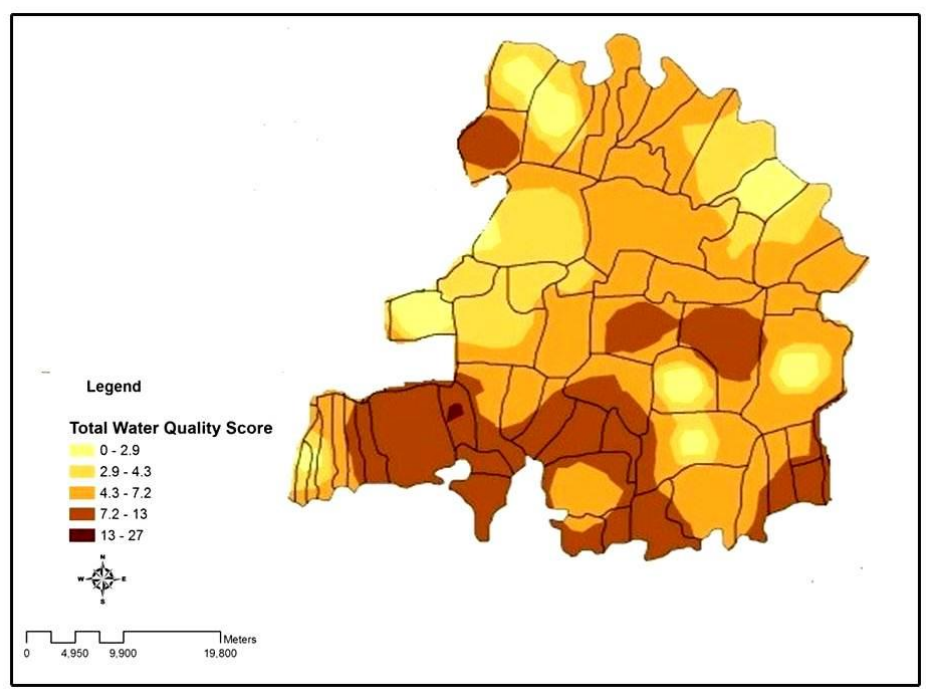

Figure 1: Ground Water Quality of Shrirampur Tehsil

It is observed that in the village Bhokar, Matapur and Eklahare has very high GWQ Index (between 13-27) therefore, water is more polluted and unsuitable for drinking due to extensive use of fertilizers and over irrigation in agriculture and discharge of molasses into the open ground.

In the villages Naur, Rampur, Kamalpur, Wadala Mahadeo, Khridi, Malunje Bk, Ladgaon, Uambargaon, Wadatgaon, Kurranpur, Gondegaon, Galnimb, Ukkhalgaon and Nursari was recorded high GWQ Index (between 7.2-.13) due to the water quality is very poor. Takalibhan, Kadit BK, Khokar, Karegaon, Matul Than, Khandala and Khanapur villages has been observed very low GWQ Index (between 0-2.9) with excellent water which is more suitable for drinking and agricultural purposes.

\section{Land Productivity Analysis}

The Land Productivity Index generated in the raster map form by integrating the reclassified soil erosion potential, the slope of the surface soil; soil type and texture and runoff factors in the raster calculator. The village area has been overlaid with land productivity index value. Higher land productivity value implies that the land in the village is more productive. It is observed that the land productivity index value ranges from 140 to 255 . The figure indicates the slicing of land productivity values into different ranges. Totally 6 ranges has been specified indicating the different magnitude of land productivity for different villages in the area. 


\section{International Journal of Science and Research (IJSR) \\ ISSN (Online): 2319-7064}

Index Copernicus Value (2013): 6.14 | Impact Factor (2015): 6.391

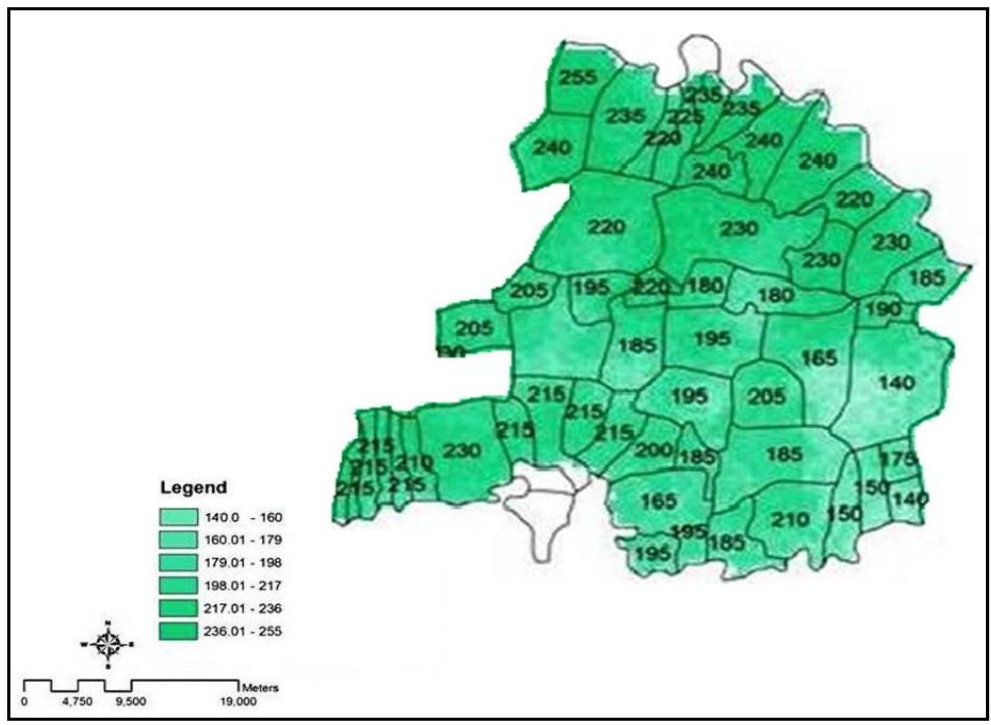

Figure 2: Land Productivity Index (LPI) Distribution for Study Area

Impact of Ground water Quality on Land Productivity Collected data are processed to examine the impact Total Water Score on Land Productivity Rating the Pearson's Coefficient of Correlation technique has been utilized.

$$
\begin{gathered}
\mathbf{r}=\frac{n(\Sigma x y)-(\Sigma x)(\Sigma y)}{\sqrt{\left(n\left(\Sigma x^{2}\right)-(\Sigma x)^{2}\right)}\left(n \times\left(\Sigma y^{2}\right)-(\Sigma y)^{2}\right)} \\
\mathbf{r}=-0.15246
\end{gathered}
$$

Value of $\mathbf{r}=\mathbf{- 0 . 1 5 2 4 6}$ which indicated the correlation between Total Water Score and Land Productivity Rating is negative. It means the village which shows Low Total Water Score (Good to Excellent Water Quality) has High Land Productivity and which shows High Total Water Score (very poor to Unsuitable for Drinking Water Quality) has Low Land Productivity.

The regression of $\mathrm{y}$ upon $\mathrm{x}$ has been calculated by the least square method according to formula:

$$
\mathbf{y}=\mathbf{a}+\mathbf{b x}
$$

Where $y$ is the dependent variable (Land Productivity Rating) and $\mathrm{x}$ is the in dependent variable (Total Water Score).

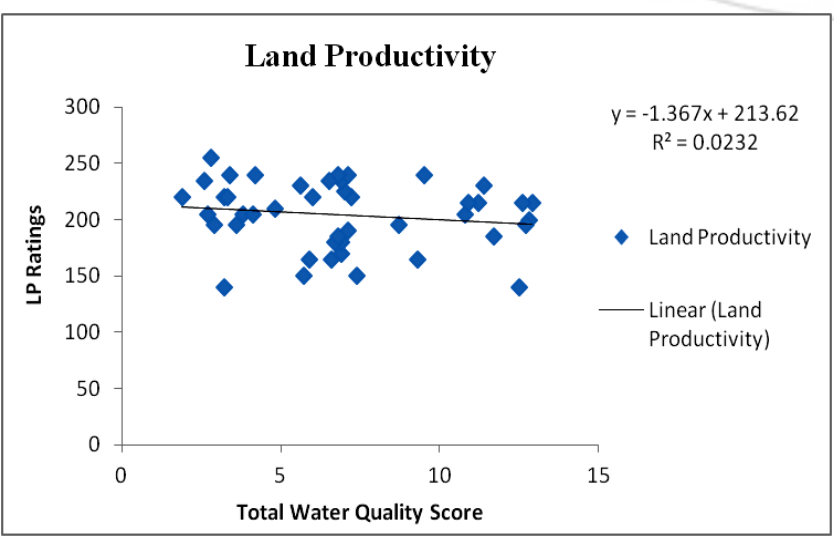

Figure 3: Correlation between Total Water Quality Score and Land Productivity Index

The line of best fit is shown in the Figure- 3 the regression coefficient indicates that increase of total water score causes for an decreased of Land productivity Ratings. The results indicate that negative impact of ground water Pollution on Land productivity in Shrirampur tahsil of Ahmednagar District.

\section{Conclusion}

Data has been analyzed regarding Ground water Quality and Land Productivity for find out impact of Ground water pollution on Land Productivity over Shrirampur Tahsil. Ground water Quality is variable over tahsil and shows the complex trends and the negative impact of GWQ Index on Land productivity Index is cleared noticed. It is observed that in the villages Kadit BK, Khokar, Karegaon, Matul Than, Khandala, Khanapur and Takalibhan has very low GWQ Index (0 to 2.9) therefore ground water quality is excellent which increased land productivity Index between 220 to 255 but in the village Bhokar, Matapur and Eklahare GWQ Index has been observed (between13-27) therefore water is more polluted which declined land productivity Index 140, 150 and 150 respectively due to extensive use of fertilizers and over irrigation in agriculture and discharge of molasses into the open ground which declining land productivity, therefore it is the need of the hour that the system of agriculture should be revitalized, to increase land productivity. For this, first and foremost step is to increased ground water and surface water quality.

\section{References}

[1] APHA (American Public Health Association Standard method for examination of water and wastewater, NW, DC 20036, 1994.

[2] Burrough, P. A. (1986): Principles of Geographical Information System for Land Resources Assessment. Oxford University Press.

[3] C. R. Ramakrishnaiah (2009): Assessment of Water Quality Index for the Groundwater in Tumkur Taluk, Karnataka State, India, E-Journal of Chemistry, 2009, 6(2), 523530 
[4] CGWB and CPCB (2000): Status of Ground Water Quality and Pollution Aspects in NCT-Delhi, January 2000.

[5] Chaudhary, B. S., Kumar, M.,Roy, A. K., \& Ruhal, D. S. (1996): Applications of RS and GIS in groundwater investigations in Sohna Block, Gurgaon District, Haryana, India. International Archives of Photogrammetry and Remote Sensing, 31(B-6), 18-23.

[6] Cholke S. P. (2012): Village Information System (V.I.S.) for watershed management in the North Ahmednagar district, Maharashtra, unpublished Ph.D. Thesis, Pune University, Pune.

[7] Kudrat and Saha (1993). Land productivity assessment and mapping through integration of satellite and terrain slope data. Journal oj the Indian Society of Remote Sensing 21, 157-166.

[8] Malla K.B. (1992): Geographic information system applications to land productivity index mapping. Asian Pacific Remote Sensing Journal 4, 129-133.

[9] Ronaldo, A. Dela Cruz (1992): The Determination of Suitable up land agriculture areas using GIS technology. Asian-Pacific Remote Sensing Journal, July, v. 5 no. 1.

[10] Saxena R K, Barthwal A K and Sohan Lal (1985): Use of satellite remote sensing techniques in exploratory and resource assessment - A case study of Nagpur district,

[11] Maharastra. Proceeding 6" Asian ConJerence on Remote Sensing, Hyderabad.

[12] Sharma and Chaudhary (2008): Land Productivity and site-suitability assessment for crop diversification using Remotely Sensed data and GIS techniques. Agropedology 2008, 18(1), 1-11.

[13] Storie, R. E. (1978): Storie Index Rating Special publication, 3203, (Division of Agricultural Science, University of California: USA) 